ORIGINAL ARTICLE

\title{
Evaluation of two analytical methods of detection for intestinal parasites in curly lettuce sold in food stalls
}

\author{
Avaliação de dois métodos analíticos para detecção de \\ parasitos intestinais em alfaces crespas vendidas em feiras de \\ rua
}

\author{
Joazir Rodrigues Oliveira', Rafaela Cássia da Cunha Pedroso ${ }^{2}$ (D), \\ Sirbene Nunes da Cunha ${ }^{3}$ (D), Vinicius Silva Castro ${ }^{4,5}$ (D) Adelino da Cunha Neto $^{5 *}$ (i) \\ ${ }^{1}$ Universidade Federal de Mato Grosso, Faculdade de Medicina, Laboratório de Parasitologia, Cuiabá/MT - Brasil \\ ${ }^{2}$ Universidade de Cuiabá, Faculdade de Medicina, Cuiabá/MT - Brasil \\ ${ }^{3}$ Universidade Brasil, Pós-graduação em Engenharia Biomédica, São Paulo/SP - Brasil \\ ${ }^{4}$ Universidade Federal do Rio de Janeiro, Instituto de Química, Pós-graduação em Ciência de Alimentos, Rio de \\ Janeiro/RJ - Brasil \\ ${ }^{5}$ Universidade Federal de Mato Grosso, Faculdade de Nutrição, Departamento de Alimentos e Nutrição, Cuiabá/MT \\ - Brasil
}

*Corresponding Author: Adelino da Cunha Neto, Universidade Federal de Mato Grosso, Faculdade de Nutrição, Bloco: B, $2^{\circ}$ andar, Avenida Fernando Correa da Costa, 2367, CEP: 78060-900, Cuiabá/MT - Brasil, email:adeneto40@gmail.com

Cite as: Oliveira, J. R., Pedroso, R. C. C., Cunha, S. N., Castro, V. S., \& Cunha Neto, A. (2022). Evaluation of two analytical methods of detection for intestinal parasites in curly lettuce sold in food stalls. Brazilian Journal of Food Technology, 25, e2021002. https://doi.org/10.1590/1981-6723.00221

\begin{abstract}
This study aimed to investigate the occurrence of parasitic structures in curly lettuce (Lactuca sativa L.) sold in food stalls open markets in Cuiabá city, in the Brazilian state of Mato Grosso (MT). For this purpose, 50 samples were evaluated using spontaneous sedimentation and centrifugal flotation methods. These techniques showed positivity in $96 \%(48 / 50)$ and $78 \%(39 / 50)$ of the samples, respectively. The sedimentation method was statistically $(p \leq 0.05)$ more effective in detecting parasitic structures of the pathogens as Entamoeba histolytica, Ascaris spp., Strongyloides spp., Larvae and Hookworm eggs, when comparing both methods. However, these methods did not differ significantly for the detection of Giardia lamblia. Ascaris spp and Entamoeba coli occurred in 64\% (32/50) and 46\% (23/50) of the positive samples, respectively, with the highest percentages observed. The occurrence of Blastocystis spp., Fasciola spp., Dipylidium caninum and Ascaris lumbricoides revealed detection exclusively by the spontaneous sedimentation method, while lodamoeba butschlii and Enterobius vermicularis were detected by centrifugalflotation procedure. These results could reinforce the need to use methods based on sedimentation and the fluctuation of parasite structures in the analysis of lettuce. The presence of parasites in lettuce by fecal origin, with recognized pathogenicity, represents a risk to consumer health and demonstrates a deficit in good agricultural practices in the production, distribution and commercialization of lettuce.
\end{abstract}

Keywords: Lactuca sativa; Protozoa; Helminths. 


\section{Resumo}

Este estudo objetivou averiguar a ocorrência de estruturas parasitárias nas alfaces crespas (Lactuca sativa), comercializadas em feiras livres e permanentes da cidade de Cuiabá-MT. Para tanto, 50 amostras foram avaliadas pelos métodos de sedimentação espontânea e centrífugo-flutuação, que revelaram positividade em 96\% (48/50) e 78\% (39/50) das amostras, respectivamente. O método de sedimentação foi mais eficaz na detecção de estruturas parasitárias dos patógenos Entamoeba histolytica, Ascaris spp., Strongyloides spp. e de larvas e ovos de Ancilostomídeo, quando comparado ao método centrífugo-flutuação, com diferença estatisticamente significativa $(p \leq 0,05)$. Contudo, estes métodos não diferiram significativamente na verificação de Giardia lamblia nas amostras. Ascaris spp. e Entamoeba coli ocorreram em 64\% (32/50) e 46\% (23/50) das amostras positivas, respectivamente, com os maiores percentuais observados. A ocorrência de Blastocystis spp., Fasciola spp., Dipylidium caninum e Ascaris lumbricoides foi revelada exclusivamente pelo método de sedimentação espontânea; lodamoeba butschlii e Enterobius vermicularis, pela centrífugo-flutuação. Estes resultados reforçam a necessidade de utilizar, na análise da alface, métodos fundamentados na sedimentação e flutuação de estruturas dos parasitas. A presença na alface de parasitas de origem fecal, com reconhecida patogenicidade, representa risco à saúde do consumidor, bem como demonstra deficiência na adoção de boas práticas agrícolas na produção, distribuição e comercialização de alfaces.

Palavras-chave: Lactuca sativa; Protozoários; Helmintos.

\section{Introduction}

Parasites are one of the disease-causing agents in humans, as well as bacteria, viruses, and protozoa, defined by the World Health Organization (WHO) (World Health Organization, 2015). Some parasites can cause diarrheal diseases, as Cryptosporidium spp., Entamoeba histolytica and Giardia spp.. Diseases that affect the abdomen (Ascaris spp., Fasciola spp. etc.), lung, liver and Central Nervous System (CNS) (Echinococcus granulosus and E. multilocularis, Taenia solium - cysticercosis). These parasites are among the pathology's causative agents, sometimes disabling the consumer's health (World Health Organization, 2015).

The WHO and the United Nations Food and Agriculture Organization (FAO) endorse the global monitoring of the following genera and species of parasites in fresh vegetables: Echinococcus granulosus; E. multilocularis; Cryptosporidium spp.; Entamoeba histolytica; Ascaris spp.; Giardia duodenalis; Fasciola spp.; Cyclospora cayetanensis; Trichuris trichiura; Balantidium coli; and Toxocara spp. (Food and Agriculture Organization of the United Nations, 2014). Other parasite species were included recently as Toxoplasma gondii and T. solium (Food and Agriculture Organization of the United Nations, 2016). Moreover, some genera such as Giardia spp., Cryptosporidium spp., Ascaris spp., and E. histolytica are related to parasites that trigger foodborne diseases most frequently (World Health Organization, 2015).

The diversity of ways in which food is consumed worldwide has influenced the occurrence and transmission of different parasites (Robertson et al., 2014). Thus, thousands of consumers have infections due to ingestion of protozoan cysts and oocysts, as well as helminth eggs and larvae. After their complete biological development, they have a direct effect on human health. This infection can also trigger childhood diarrhea and consequences on children's growth rate, especially in developing countries (Doyle, 2003).

The detection of parasitic structures in leaves and vegetables demonstrates the potential carrier parasites to humans and, consequently, a risk to public health (Pinto et al., 2018). Draeger et al. (2019) have suggested that outbreaks triggered by intestinal parasites often do not have the determination of 
the parasite specie, in view of a low percentage of species identification (between $25 \%$ and $30 \%$ ) was verified for the cases reported from 2016 to 2017. For this, food-borne outbreaks associated with fresh products in Brazil should be monitored to assess control strategies better to prevent diseases (Machado et al., 2018). Outbreaks linked to fruits and vegetables represented an average of 4.3 cases per year, or $0.6 \%$ of all food-outbreak reported from 2008 to 2014 (Elias et al., 2018). However, the investigation of outbreaks by parasites requires technician's expertise in evaluating ecological and epidemiological aspects of natural food contamination, one time that food is a complex matrix, and this complexity requires human resources trained in microscopy and analytical methods for accurate diagnosing of parasites in food (Barbosa, 2015).

Lettuce is among the third vegetables, most produced and consumed in Brazil, representing approximately 19 billion dollars to Brazil in 2016 (Brasil, 2017). An increase in good social-environmental measures is desired by consumers, even if it affects its price (Echer et al., 2016).

The occurrence of parasitic structures in lettuce produced in Brazil was analyzed in five regions, in farms of production, commercialization area, and their consumption habits, as well as in farm production (Barbosa et al., 2016), horticulture fair (Tiyo et al., 2016), open markets (Medeiros et al., 2019; Ramos et al., 2019; Pinto et al., 2018; Oliveira et al., 2016), supermarkets (Almeida et al., 2016), bistro (Silva et al., 2017), and two or more types of leaves and vegetable commercialization (Ambrozim et al., 2017; Luz et al., 2017; Trevisan et al., 2017; Brauer et al., 2016; Nogueira et al., 2016; Silva et al., 2016). These mentioned studies were carried out in the Southeast, North, Northeast, South and Midwest regions of Brazil, using diagnostic techniques of spontaneous sedimentation or centrifugal - flotation, or the quantitative FLOTAC technique, based on the flotation of eggs and cysts (Pedroso et al., 2020, Ramos et al., 2019).

The techniques mentioned above are used to analyze leaves, fruits, and vegetables, individually or in combination (Mesquita et al., 2015; Barnabé et al., 2010; Quadros et al., 2008; Paula et al., 2003). These techniques are procedural adaptations used in clinical samples. Fluctuation techniques have the principle that nematode eggs and protozoan oocysts can float in saturated solutions. On the other hand, sedimentation techniques are indicated for the recovery of heavy eggs that do not float in saturated solutions, as is the case of trematode eggs and also some cestodes eggs (Táparo et al., 2006).

In the state of Mato Grosso (MT), studies on the occurrence of parasitic structures in lettuce were carried out at retail supermarkets in Cuiabá (Alves et al., 2013) and at open marketing in Tangará da Serra (Ferro et al., 2012). Therefore, the present study aimed to verify the occurrence of parasitological structure in crisp lettuce (Lactuca sativa L.) commercialized in open-markets in Cuiabá (MT) and to compare spontaneous sedimentation and centrifuge-flotation methods.

\section{Materials and methods}

During one-year (from January 2019 to January 2020), 50 samples of curly lettuce (L. sativa) from conventional planting were collected in five open-markets (one permanent and four eventually open-market) in Cuiabá (MT). The sample collection was performed randomly and for convenience. The lettuce plant was packed in a plastic bag provided by the market employee, stored in an isothermal box, and transported to the Parasitology laboratory.

In the laboratory, all lettuces were weighed, removed from the bag, washed, and immersed in $250 \mathrm{ml}$ of $0.03 \%$ Extram MA02® (Merck, Darmstadt, Germany) aqueous solution (Alves et al., 2013). The leaves were rubbing on both sides with manual movements using our hands to put on a sterile glove. The residual wash was filtered through gauze over a nylon sieve into the Imhoff cup. An aliquot of approximately $15 \mathrm{ml}$ was 
transferred to a conical tube, the volume remaining in the Imhoff cup was left to stand for six hours. After, two aliquots of the sediment were removed to prepare a microscope slide, stained with Lugol, and covered with coverslips for observation under the optical microscope. The $15 \mathrm{ml}$ of the residual wash transferred to a conical tube was centrifuged at $2500 \mathrm{rpm}(1.048 \mathrm{~g})$ (Excelsa Baby® Centrifuge, 206BL) for one minute. Subsequently, the sediment was placed in a tube and a saturated sugar solution was added to the edge of the tube, on which a microscope slide was placed for 5 minutes. Afterwards, the slide in contact with the solution facing upwards, in which a drop of Lugol was included, was covered with a coverslip for further analysis. The examination of all slides was performed using a binocular optical microscope (Micronal, Olympus $\left.\mathrm{CBB}{ }^{\circledR}\right)$, in which the size of the parasitic structures was measured with the aid of an eyepiece and a micrometric slide (Olympus $\mathrm{CBB} \circledast$ ). The slides were viewed with the aid of objective lenses 10x and 40x. The parasitic structures detected were identified through biometric and image data, compared to those contained in the Atlas of Parasitology (Anderson, 2006; Bowman et al., 2006; Cimerman \& Franco, 2009; Foreyt, 2005).

In the comparative assessment of groups, the data set was compared using the Student's t-test. The comparison of data for each group, genus, and species was performed statistically by the Kruskal-Wallis test. Thus, in order to verify if there was a significant difference between the methods, with a significance level of $5 \%$, the statistical analyzes were performed in the PAST. 3 software (Softpedia ${ }^{\circledR}$ ) (PAST, 2018).

\section{Results and discussion}

Lettuces processed by the spontaneous sedimentation method showed positivity for parasitic structures in $96 \%(48 / 50)$ of the samples. While in those samples analyzed using the centrifuge-flotation method, $78 \%(39 / 50)$ were positive (Table 1). The sedimentation method is the most widely used worldwide and is considered the gold standard method for analyzing fruits and vegetables (Medeiros et al., 2019; Ismail, 2016).

Numerous pathogenic parasites to humans are susceptible to transmission by water, fruits, and raw or undercooked vegetables, constituting a significant public health problem (Barbosa, 2015). By using two different methods of parasitological analysis, we found that the lettuces sold at the open-markets in Cuiabá (MT) showed a high frequency of parasitic structures of the different family, genus, and species of the protists (Protozoa) and helminths (Metazoa) (Table 1).

The Ascaris spp. egg represented 64\% (32/50), and the Entamoeba coli cyst 46\% (23/50) of the parasitic structures detected in the lettuces, thus constituting the highest percentages of positivity (Table 1). Similar results for the presence of Ascaris spp. were found in lettuces evaluated by Corrêa et al. (2012), and Vollkopf et al. (2006) in the state of Mato Grosso do Sul (MS). Otherwise, for E. coli cysts, these percentages were similar to the results observed by Beletini et al. (2014) and Nomura et al. (2015) in the state of Paraná (PR). Using a single analytical method (spontaneous sedimentation), E. coli cyst was observed in similar percentages in lettuces sold in open-markets in Diamantina, in the state of Minas Gerais (MG) (Silva et al., 2015), and other open-market in Parnaíba, in the state of Piaui (PI) (Melo et al., 2011).

In the fifty samples of lettuce, thirteen genera and eight species of parasites belonging to the groups of protozoa and metazoa were observed, and parasite species were detected using the two applied methods (Table 1). 
Table 1. Frequency (\%) of positive results for parasitic structures in lettuce $(n=50)$ from open and permanent markets in the municipality of Cuiabá (MT), diagnosed by spontaneous sedimentation and centrifugal flotation methods.

\begin{tabular}{|c|c|c|c|}
\hline \multirow[b]{2}{*}{ Parasitic structures } & \multicolumn{2}{|c|}{ Diagnostic method } & \multirow{2}{*}{$\begin{array}{c}\text { Test Kruskal/Wallis } \\
\text { Value } p \leq 0.05\end{array}$} \\
\hline & $\begin{array}{c}\text { Spontaneous } \\
\text { sedimentation \% }(n / N)\end{array}$ & $\begin{array}{c}\text { Centrifuge- } \\
\text { flotation } \%(n / N)\end{array}$ & \\
\hline \multicolumn{4}{|l|}{ PROTOZOA } \\
\hline \multicolumn{4}{|l|}{ Amoebae } \\
\hline Entamoeba coli cysts & $46 \%(23 / 50)$ & $24 \%(12 / 50)$ & $0.0217 *$ \\
\hline E. histolytica/dispar cysts & $26 \%(13 / 50)$ & $12 \%(6 / 50)$ & $0.0465^{*}$ \\
\hline Endolimax nana cysts & $8 \%(4 / 50)$ & $2 \%(1 / 50)$ & 0.1808 \\
\hline Iodamoeba butschlii cysts & $0 \%$ & $4 \%(2 / 50)$ & 0.1655 \\
\hline \multicolumn{4}{|l|}{ Flagellates } \\
\hline Giardia lamblia cysts & $16 \%(8 / 50)$ & $14 \%(7 / 50)$ & 0.7805 \\
\hline \multicolumn{4}{|l|}{ Sporozoa } \\
\hline Blastocystis spp cysts & $4 \%(2 / 50)$ & $0 \%$ & 0.1655 \\
\hline \multicolumn{4}{|l|}{ METAZOA } \\
\hline \multicolumn{4}{|l|}{ Trematoda } \\
\hline Fasciola spp egg & $6 \%(3 / 50)$ & $0 \%$ & 0.0801 \\
\hline \multicolumn{4}{|l|}{ Cestoda } \\
\hline Dipylidium caninum egg & $2 \%(1 / 50)$ & $0 \%$ & 0.3173 \\
\hline Taenia spp egg & $4 \%(2 / 50)$ & $4 \%(2 / 50)$ & 1 \\
\hline \multicolumn{4}{|l|}{ Nematoda } \\
\hline Strongyloides spp larvae & $30 \%(15 / 50)$ & $6 \%(3 / 50)$ & $0.0018^{*}$ \\
\hline Hookworm larvae & $18 \%(9 / 50)$ & $2 \%(1 / 50)$ & $0.0079 *$ \\
\hline Hookworm egg & $20 \%(10 / 50)$ & $2 \%(1 / 50)$ & $0.0042 *$ \\
\hline Ascaris spp egg & $64 \%(32 / 50)$ & $28 \%(14 / 50)$ & $0.0003 *$ \\
\hline Ascaris lumbricoides egg & $6 \%(3 / 50)$ & $0 \%$ & 0.0801 \\
\hline Enterobius vermicularis egg & $0 \%$ & $2 \%(1 / 50)$ & 0.3271 \\
\hline \multicolumn{4}{|l|}{ Non-parasitic structures } \\
\hline Free-living nematode larvae & $36 \%(18 / 50)$ & $2 \%(1 / 50)$ & NS \\
\hline Mite Egg & $64 \%(32 / 50)$ & $62 \%(31 / 50)$ & NS \\
\hline
\end{tabular}

NS = not statistically evaluated; * there is statistical difference between evaluated groups.

In the discussion, we highlighted the parasites pathogenic to humans that we observed in the lettuces of the open-markets in Cuiabá (MT), such as the protozoa E. histolyticaldispar (26\%) and G. lamblia (16\%). Among the metazoa (helminths), Hookworm's presence (larvae and egg, 18\% and 20\%), Ascaris spp. (64\%), A. lumbricoides (6\%), Enterobius vermicularis (2\%), Fasciola spp. (6\%), Taenia spp. (4\%) and Strongyloides spp. (30\%) represented a direct risk to consumer's health (Table 1). In addition, commensal parasites such as the cyst of E. coli (46\%), Endolimax nana (8\%), Iodamoeba butschlii (4\%), Bastocystis spp. (4\%), and or animal pathogens such as Dipylidium caninum (2\%) were verified. 
Previous monitoring of intestinal parasites in lettuce of supermarket, human and animal feces in Cuiabá, showed the occurrence of helminths such as: Ascaris spp.; A. lumbricoides; Hookworms (Ancylostoma spp.); D. caninum; E. vermicularis; Hymenolepis nana; Strongyloides spp.; and Taenia spp. (Alves et al., 2013; Ramos et al., 2013; Bastos et al., 2008). Protozoa also were detectable as: Entamoeba sp.; E. coli; E. histolytica/dispar; E. nana; and G. lamblia (Alves et al., 2013; Ramos et al., 2013; Bastos et al., 2008). In lettuces, the presence of intestinal parasites related to humans and animals reveals that in Cuiabá some factors have influenced the contamination of leaves, for instance: poor economic conditions; inadequate sanitation practices (water and sewage treatment); pollution of gardens soil; and water bodies used in irrigation with fecal material (Amaechi et al., 2016). These factors had an effect upon this scenario for a long time, as after almost ten years later the same parasites were observed in lettuce cultivated in Cuiabá.

High contamination rates of helminths transmitted by the soil such as A. lumbricoides, Hookworms and Strongyloides spp. in vegetables can be significantly influenced by the high infection rates in humans. In addition to the resistance and persistence of these organisms in the environment, the survivability was estimated in months or years (Rostami et al., 2016). It is noteworthy that the presence of these helminths in the lettuce indicates faecal contamination (Amaechi et al., 2016).

Among the helminths, Ascaris spp., A. lumbricoides, E. vermicularis, Fasciola spp., Taenia spp. were detected in lettuce and represent intestinal pathogens that have the oral route as the main way of infection of the organism (PAHO, 2003). In addition, Hookworm and Strongyloides spp. had the skin penetration as the main route of pathogenicity (Utaaker \& Robertson, 2015). However, the ingestion of these parasites can also cause infections in humans (PAHO, 2003).

Vegetables are contaminated by parasitic structures on the farm during production and harvest, via the soil contamination, irrigation or washing water and/or by infected food handlers (Yusof et al., 2017; Ishaku et al., 2013). These routes influence the contamination of lettuces on the farms, as well as those lettuces exposed in commercial places. Ascaris spp., Fasciola spp., and Taenia spp. among metazoa (helminths), and E. histolytica and G. lamblia among protozoa, were present in the evaluated lettuce, and these parasitic structures are highlighted as important causative agents of infection transmitted by foods of vegetable origin by the WHO and United Nations Food and Agriculture Organization (Food and Agriculture Organization of the United Nations, 2016). Among the important parasites, which have priority control, we still have the helminths $A$. duodenale and H. nana (World Health Organization, 2015), which were also found in lettuces. An interesting point is that Cuiabá has different ways to commercialize lettuces, for instance: open markets (permanents or not); greengrocer's shop; warehouse; markets; or super/hypermarkets. However, lettuces are usually displaying on shelves at room temperature in the open market and exposed to dust. In addition, sometimes a market employee can be spray water in leaves to maintain humidity.

Pedroso et al. (2020) reported in their review that A. lumbricoides, Strongyloides spp., and S. stercolares were the helminths frequently detected in lettuces, as well as Ascaris spp., and the hookworm group (Necator spp., and Ancylostoma spp.). These parasites are widely distributed in the lettuce production chain, present in lettuces from the farm, super/hypermarket, greengrocery, fairs, and restaurants, spread throughout the five regions of Brazil (Pedroso et al., 2020).

Lettuces commercialized in different regions of Brazil also showed positivity for parasites, such as: D. caninum (Ambrozim et al., 2017; Duque et al., 2014); E. vermicularis (Ambrozim et al., 2017; Costantin et al., 2013; Soares \& Cantos, 2005); F. hepatica (Luz et al., 2017; Duque et al., 2014; Ferro et al., 2012); H. nana (Ambrozim et al., 2017; Luz et al., 2017: Duque et al., 2014; Santos \& Peixoto, 2007; Soares \& Cantos, 2005; Silva et al., 2005); and Taenia spp. (Luz et al., 2017; Ribeiro et al., 2015; Duque et al., 2014; Gomes Neto \& Pessoa., 2012; Belinelo et al., 2009; Santos \& Peixoto, 2007; Freitas et al., 2004). In addition, there are reports of the $D$. caninum and $E$. vermicularis species in lettuce samples from vegetable farms, at the beginning of the production chain (Terto et al., 2014; Costantin et al., 2013). Furthermore, the D. caninum, E. vermicularis, $H$. nana and $F$. hepatica species were detected in lettuces commercialized in restaurant, which is associated with the final stage of the production chain (Macena et al., 2018; Montanher et al., 2007), thus demonstrating the inefficiency of hygienic practices in the production of this product. 
The presence of E. vermicularis, H. nana, and Taenia spp. in lettuce could indicate a potential fecal contamination by human origin (Pedroso et al., 2020; Federer et al., 2016; Georgiev, 2001). The presence of D. caninum, probably indicated the contamination with feces of dogs or cats (Pan American Health Organization, 2003), whereas $F$. hepatica can be related to fecal contamination of domestic and wild animals, as well as human feces (World Health Organization, 2015).

The inefficiency of hygienic practices or no application of this tool in the management of lettuce from the vegetable farms was reported by Pedroso et al. (2020), where the occurrence of geohelminths and other intestinal parasites of animals and humans in lettuce were observed. In addition, the presence of E. vermicularis was verified in lettuce from the farm (Costantin et al., 2013), in commercialization (Ambrozim et al., 2017), and in a restaurant (Macena et al., 2018). Different contamination source indicated that this vegetable had contact with human feces, directly or indirectly, through vehicles of contamination such as water, dust, cockroaches, flies, or contaminated human hand, during the process of obtaining it until consumption (Amaechi et al., 2016; Oyeyemi et al., 2016; Adenusi et al., 2015). The occurrence in lettuce of this parasite that is exclusive to human reinforces the hypothesis of poor hygiene habits (Georgiev, 2001).

Commensal protozoans from the gastrointestinal tract of animals and humans, such as E. coli, E. nana, and Blastocystis spp., were present in lettuces sold at free markets in Cuiabá (Table 1), as well as the cysts of the pathogenic protozoa E. histolytica and G. lamblia. In Brazil, in those lettuces collected in vegetable gardens, the occurrence of $G$. lamblia cyst was observed among pathogenic protozoa, and E. nana among commensals (Silva et al., 2019). Pathogenic protozoa such as E. histolytica and G. lamblia were detected in lettuces obtained from restaurants (Silva et al., 2019; Macena et al., 2018; Silva et al., 2017; Queiroz et al., 2014). Both commensal and pathogenic protozoa mentioned above were detected in lettuces at vegetable in super/hypermarket, greengrocer's shop, and fairs (Rodrigues et al., 2020, Ambrozim et al., 2017; Luz et al., 2017; Silva et al., 2016; Gomes Neto \& Pessoa, 2012). In the lettuces obtained in fairs and supermarket, the protozoa Blastocystis hominis (Rodrigues et al., 2020), and I. butschlii were also found (Silva et al., 2016; Gomes Neto \& Pessoa, 2012). The $B$. hominis and I. butschlii also were observed in lettuce collected in restaurants (Montanher et al., 2007). All the protozoa mentioned above were observed in the lettuces at the fairs in Cuiabá (Table 1).

The presence of pathogenic protozoa, such as E. histolytica and G. lamblia, and commensal parasites as Iodamoeba, Endolimax, and B. hominis indicated fecal contamination, as the habitat of these pathogens is the human intestine. Other commensal parasites live in the intestinal microbiota of birds, human or nonhuman primates and other mammal animals (Stensvold et al., 2012; Leelayoova et al., 2008; Leelayoova et al., 2004; Orlandi et al., 2002). Among commensal parasites, there are reports of B. hominis, causing intestinal inflammation (Hirata et al., 2007), pathogenicity that leads to abdominal pain and diarrhea (Hayashi et al., 2006). Pathogenic protozoa may have contaminated lettuce through the soil in the case of E. histolytica that survive in this environment for eight days at temperatures between 28 and $34{ }^{\circ} \mathrm{C}$, and G. lamblia by the water where this specie is estimated to survive up to one month at $21^{\circ} \mathrm{C}$ (PAHO, 2003).

When comparing the spontaneous sedimentation method "Gold Standard" with the centrifuge-flotation method, there was a difference between the percentages and frequencies obtained for each methodology (Table 1). The Student's t-test revealed that the data set for each method showed a significant difference $(p=0.0022)$. Demonstrating that the spontaneous sedimentation method was more effective in detecting parasitic structure (larvae, eggs, cysts and oocysts) of the different families, groups, genera and species of helminths and protozoa in the lettuces analyzed in Cuiabá (MT) (Table 1). Corroborating to the results obtained in our study, some studies analyzed vegetables such as lettuce in the Dourados (MS), Pelotas (RS), Cascavel (PR), Lages (SC), and São Paulo (SP) (Quadros et al., 2008; Barnabé et al., 2010; Corrêa et al., 2012; Antunes et al., 2013; Beletini et al., 2014), and the spontaneous sedimentation method was more efficient in detecting parasitic structures, with significant statistically differences.

The effectiveness of spontaneous sedimentation and centrifugation methods in detecting parasitic structure in lettuce (larvae, eggs, cysts, and oocysts) of each of the thirteen genera, eight species and a group of intestinal parasites was verified using the statistical test of Kruskal-Wallis with significance level $p \leq 0.05$. Both methods were able to detect protozoa, cysts of the species E. coli $(p=0.0217)$, E. histolytica 
$(p=0.0465), E$. nana $(p=0.1808)$ and G. lamblia $(p=0.7805)$. A significant statistical difference was observed in detecting the E. coli and E. histolytica species' cysts, thus showing the higher effectiveness of the spontaneous sedimentation method (Table 1). These results were similar to those obtained in studies in which this method was effective in detecting the E. coli protozoa in lettuces (Beletini et al., 2014; Barnabé et al., 2010; Queiroz et al., 2014; Quadros et al., 2008) and also E. histolytica/dispar (Barnabé et al., 2010; Queiroz et al., 2014; Quadros et al., 2008). However, it differed from the results obtained by Queiroz et al. (2014) and Quadros et al. (2008); therefore, we did not obtain a significant difference between the methods used to detect G. lamblia, which could contrast with the studies cited in which the spontaneous sedimentation method was more effective in detecting this protozoan. The presence of the species I. butschlii $(p=0.1655)$ was also verified only by the centrifugal-flotation method, and also the genus Blastocystis spp. ( $p=0.1655)$ due to spontaneous sedimentation in lettuces at the open markets in Cuiabá (MT).

Among the helminths, the two methods applied were able to detect parasitic structures such as larvae of Strongyloides spp. $(p=0.0018)$, Hookworm (larvae: $p=0.0079$ and eggs: $p=0.0042)$, Ascaris spp. eggs $(p=0.0003)$ and Taenia spp. $(\mathrm{p}=1)$. However, the eggs of A. lumbricoides $(p=0.0801)$, Fasciola $\mathrm{spp}$. $(p=0.0801)$ and D. caninum $(p=0.3173)$ were detected only by the spontaneous sedimentation method, whereas the eggs of $E$. vermicularis $(0.3271)$ were detected by centrifuge-flotation (Table 1). A significant difference $(p \leq 0.05)$ was observed between the two methods for detecting Strongyloides spp., and Hookworm, also for the eggs of Hookworm and Ascaris spp. (Table 1). It is noteworthy the effectiveness of the spontaneous sedimentation method in detecting these parasitic structures. Similar results in lettuce and other vegetables were described for the detection of Ascaris spp. (Fagbenro et al., 2016; Mesquita et al., 2015; Corrêa et al., 2012; Quadros et al., 2008), Hookworm (larvae and eggs) (Fagbenro et al., 2016; Mesquita et al., 2015; Corrêa et al., 2012), and Strongyloides spp. (Fagbenro et al., 2016; Mesquita et al., 2015; Queiroz et al., 2014). The similarity was also observed for the predominant detection of A. lumbricoides by spontaneous sedimentation (Fagbenro et al., 2016) and E. vermicularis centrifugeflotation (Corrêa et al., 2012) in lettuce and other vegetables.

The high frequency of detecting parasites in vegetables can be influenced by geographic location, climate, sanitary conditions, water management, and fertilizer or manure contamination. Knowledge of producers and consumers about the possibility of parasite transmission by vegetables and hygiene habits of the population can influence the higher or lesser detection of parasites in lettuce (Fagbenro et al., 2016; Alhabbal, 2015; Eraky et al., 2014). The analytical procedure used to float or sediment the parasitic structures can also influence the detection of these structures (Ezatpour et al., 2013).

To avoid contamination in vegetables and leaves, information regarding the parasites and the consequences of the infection is encouraged for producers and consumers. The understanding of the route of contamination and how to avoid the presence in these products can minimize the risks of food infection and promoting better consumer health.

\section{Conclusion}

The analytical methods of spontaneous sedimentation and centrifugal-flotation applied to lettuces sold in the open-markets in Cuiabá city (MT/Brazil) showed leaves contaminated with parasitic structures, such as larvae and helminth eggs, protozoan cysts, and oocysts. In addition, the spontaneous sedimentation method was more effective in detecting parasitic structures. Lettuces from Cuiabá city can be considered a potential source of infection in consumers. The present study highlighted the need to implement health education for producers, traders, and consumers. Our study also reinforced the need to increase investments for more preventive actions by environmental and health surveillance agencies in the Brazilian municipalities with respect to the lettuce production chain. 


\section{Reference}

Adenusi, A. A., Abimbola, W. A., \& Adewoga, T. O. S. (2015). Human intestinal helminth contamination in pre-washed, fresh vegetables for sale in major markets in Ogun State, southwest Nigeria. Food Control, 50, 843-849. http://dx.doi.org/10.1016/j.foodcont.2014.10.033.

Alhabbal, A. T. (2015). The prevalence of parasitic contamination on common sold vegetables in Alqalamoun region. International Journal of Pharmaceutical Sciences Review and Research, 30(1), 94-97.

Almeida, E. M. S. M., Rodrigues, K. M., Gonçalves, J. S., Ramos, G. N. P., \& Morais, A. B. (2016). Análises parasitológicas em folhas de alface comercializadas em supermercados da cidade de Patos-PB. Temas em Saúde, 16(3):287-301.

Alves, A. S., Cunha-Neto, A., \& Rossignoli, P. A. (2013). Parasitos em alface-crespa (Lactuca sativa L.), de plantio convencional, comercializada em supermercados de Cuiabá, Mato Grosso, Brasil. Revista de Patologia Tropical, 42(2), 217-229. http://dx.doi.org/10.5216/rpt.v42i2.25529.

Amaechi, E. C., Ohaeri, C. C., Ukpai, O. M., \& Adegbite, R. A. (2016). Prevalence of parasitic contamination of salad vegetables in Ilorin, North Central, Nigeria. Momona Ethiopian Journal of Science, V8(2), 136-145. http://dx.doi.org/10.4314/mejs.v8i2.3.

Ambrozim, F. M., Pezzin, J., Gradella, D. B. T., \& Souza, M. A. A. (2017). Enteroparasites in vegetables marketed in an ancient Brazilian city. Revista de Salud Publica, 19(5), 635-640. http://dx.doi.org/10.15446/rsap.v19n5.57141. PMid:30183811.

Anderson, D. C. (2006). Nematode parasites of vertebrates: their development and transmission (2nd ed., 650p.). Cambridge: CABI Publishing.

Antunes, L., Vieira, J. N., Pereira, C. P., Bastos, C. G. G., Nagel, A. S., \& Villela, M. M. (2013). Parasitos em hortaliças comercializadas no sul do Rio Grande do Sul, Brasil. Revista de Ciências Médicas e Biológicas, 12(1), 45-49. http://dx.doi.org/10.9771/cmbio.v12i1.6543.

Barbosa, R. L. (2015). Perspectives on foodborne parasites. Advances in Food Technology and Nutritional Sciences Openventio Journal., 1(4), 82-83. http://dx.doi.org/10.17140/AFTNSOJ-1-114.

Barbosa, V. A. A., Cardoso Filho, F. C., Silva, A. X. L., Oliveira, D. G. S., Albuquerque, W. F., \& Barros, V. C. (2016). Comparação da contaminação de alface (Lactuca sativa) proveniente de dois tipos de cultivo. Revista Brasileira de Higiene e Sanidade Animal, 10(2), 231-242.

Barnabé, A. S., Ferraz, R. R. N., Pincinato, E. C., Gomes, R. C. F., Galleguillos, T. G. B., Cerqueira, M. Z., Soares, E. G. L., Lage, P. S., Araújo, C. X., Szamszoryk, M., \& Massara, C. L. (2010). Análisis comparativo de los métodos para la detección de parásitos en las hortalizas para el consumo humano. Revista Cubana de Medicina Tropical, 62(1), 21-27. PMid:23431633.

Bastos, W. R., Rodrigues, J., \& Pinheiro, S. F. (2008). Prevalência de enteroparasitoses e fatores associados em escolares da rede pública de ensino municipal da região oeste de Cuiabá-MT, Brasil, 2007. Boletim de Saúde, 22(2), 17-28. Retrieved in 2021, January 02, from http://www.boletimdasaude.rs.gov.br/conteudo/2899/preval\%C3\%AAncia-de-enteroparasitoses-e-fatoresassociados-em-escolares-da-rede-p\%C3\%BAblica-de-ensino-municipal-da-regional-oeste-de-cuiab\%C3\%A1-mt,-brasil,-2007.

Beletini, L. F., Takizawa, L. H. H., \& Takizawa, M. G. (2014). Enteroparasitas em alfaces (Lactuca sativa) variedade crespa previamente tratadas com desinfetantes. Revista Thêma et Scientia, 4(1), 150-157. Retrieved in 2021, January 02, from http://www.themaetscientia.com/index.php/RTES/article/view/203/212.

Belinelo, V. J., Gouvêia, M. I., Coelho, M. P., Zamprogno, A. C., Fianco, B. A., \& Oliveira, L. G. A. (2009). Enteroparasitas em hortaliças comercializadas na cidade de São Mateus, ES, Brasil. Arquivos de Ciências da Saúde da UNIPAR, 13(1), 33-36. Retrieved in 2021, January 02, from https://revistas.unipar.br/index.php/saude/article/view/2794.

Bowman, D. D., Lynn, R. C., Eberhard, M. L., \& Alcatraz, A. (2006). Parasitologia veterinária de Georgis (8. ed., 422p.). Barueri: Manole.

Brasil. Confederação da Agricultura e Pecuária do Brasil. (2017). Mapeamento e qualidade da cadeia produtiva das hortaliças no Brasil. /Confederação da Agricultura e Pecuária do Brasil (79p.). Brasília: CNA.

Brauer, A. M. N. W., Silva, J. C., \& Souza, M. A. A. (2016). Distribuição de enteroparasitos em verduras do comércio alimentício do município de São Mateus, Espírito Santo, Brasil. Natureza Online, 14(1), 55-60.

Cimerman, B., \& Franco, M. A. (2009). Atlas de Parasitologia: artrópodes, protozoários e helmintos (105p.). São Paulo: Atheneu.

Corrêa, J. R., Santos, P. C. P., \& Mauad, J. R. C. (2012). Qualidade higiênico-sanitária de alface (Lactuca sativa) comercializada em supermercados em Dourados - MS. Scientia Agraria, 13(2), 53-58. http://dx.doi.org/10.5380/rsa.v13i2.40884

Costantin, B. S., Gelatti, L. C., \& Santos, O. (2013). Avaliação da contaminação parasitológica em alfaces: um estudo no sul do Brasil. Revista Fasem Ciências, 2(1), 9-22. Retrieved in 2021, January 02, from https://revista.fasem.edu.br/index.php/fasem/article/view/30.

Doyle, M. E. (2003). Foodborne parasites - a review of the scientific literature review. Madison: University of Wisconsin.

Draeger, C. L., Akutsu, R. C. C., Zandonadi, R. P., Silva, I. C. R., Botelho, R. B. A., \& Araújo, W. M. C. (2019). Brazilian Foodborne Disease National Survey: evaluating the landscape after 11 years of implementation to advance research, policy, and practice in public health. Nutrients, 11(1), 40. http://dx.doi.org/10.3390/nu11010040. PMid:30585184.

Duque, I. L. L., Vieira, V. F., Damásio, J. M. A., \& Mottin, V. D. (2014). Pesquisa de ovos de helmintos e oocitos de protozoários em alfaces (Lactuca sativa) comercializadas em feiras livres e supermercados. Veterinária em Foco, 11(2), 104-111.

Echer, R., Lovatto, P. B., Trecha, C. O., \& Schiedeck, G. (2016). Alface à mesa: implicações socioeconômicas e ambientais da semente ao prato. Revista Thema, 3(3), 17-29. http://dx.doi.org/10.15536/thema.13.2016.17-29.361. 
Elias, S. O., Decol, L. T., \& Tondo, E. C. (2018). Foodborne outbreaks in Brazil associated with fruits and vegetables: 2008 through 2014. Food Quality and Safety, 2 (4), 173-181. http://dx.doi.org/10.1093/fqsafe/fyy022.

Eraky, M. A., Rashed, S. M., Nasr, M. E.-S., El-Hamshary, A. M. S., \& El-Ghannam, A. S. (2014). Parasitic contamination of commonly consumed fresh leafy vegetables in Benha, Egypt. Journal of Parasitology Research, 2014, 613960. http://dx.doi.org/10.1155/2014/613960. PMid:25024845.

Ezatpour, B., Chegeni, A.S., Abdollahpour, F., Aazami, M., \& Alirezaei, M. (2013). Prevalence of parasitic contamination of raw vegetables in Khorramabad, Iran. Food Control, 34, 92-95. http://dx.doi.org/10.1016/j.foodcont.2013.03.034.

Fagbenro, M. T., Mogaji, H. O., Oluwole, A. S., Adeniran, A. A., Alabi, O. M., \& Ekpo, U. F. (2016). Prevalence of Parasites found on Vegetables and Perception of Retailers and Consumers about Contamination in Abeokuta Area of Ogun State, Nigeria. Clinical Microbiology \& Case Reports, 2(1):025.

Federer, K., Armura-Fernandez, M.T., Gori, F., Hoby, S., Wenker, C., \& Deplazes, P. (2016). Detection of taeniid (Taenia spp., Echinococcus spp.) eggs contaminating vegetables and fruits sold in European markets and the risk for metacestode infections in captive primates. International Journal for Parasitology: Parasites and Wildlife, 5, 249-253.

http://dx.doi.org/10.1016/j.ijppaw.2016.07.002

Ferro, J. J. B., Costa-Cruz, J. M., \& Barcelos, I. S. C. (2012). Avaliação parasitológica de alfaces (Lactuca sativa) comercializadas no município de Tangará da Serra, Mato Grosso, Brasil. Revista de Patologia Tropical, 41(1), 47-54 http://dx.doi.org/10.5216/rpt.v41i1.17745.

Food and Agriculture Organization of the United Nations - FAO. World Health Organization - WHO. (2016). Guidelines on the Application of General Principles of Food Hygiene to the Control of Foodborne Parasites. Cac/Gl 88-2016. Codex Alimentarius International Food Standard. Rome: FAO/WHO. Retrieved in 2021, January 02, from www.codexalimentarius.org.

Food and Agriculture Organization of the United Nations - FAO. World Health Organization - WHO. 2014. Multicriteria-based ranking for risk management of food-borne parasites. Microbiological Risk Assessment Series No. 23 (302p.). Rome: FAO/WHO. Retrieved in 2021, January 02, from http://www.fao.org/food/food-safety-quality.

Foreyt, W. J. (2005). Parasitologia veterinária: manual de referência (5. ed., 204p). São Paulo: Roca.

Freitas, A. A., Kwiatkowski, A., Nunes, S. C., Simonelli, S. M., \& Sangioni, L. A. (2004). Avaliação parasitológica de alfaces (Lactuca sativa) comercializadas em feiras livres e supermercados do município de Campo Mourão, Estado do Paraná. Acta Scientiarum. Biological Sciences, 26(4), 381-384. http://dx.doi.org/10.4025/actascibiolsci.v26i4.1514.

Georgiev, V. (2001). Chemotherapy of enterobiasis (Oxiuriasis). Expert Opinion on Pharmacotherapy, 2(2), 267-275. http://dx.doi.org/10.1517/14656566.2.2.267. PMid:11336585.

Gomes Neto, N. J., \& Pessoa, R. L. M. L. (2012). Bacterial counts and the occurrence of parasites in lettuce (Lactuca sativa) from different cropping systems in Brazil. Food Control, 28(1), 47-51. http://dx.doi.org/10.1016/j.foodcont.2012.04.033.

Hayashi, M., Inamori, M., Goto, K., Akiyama, T., Fujita, K., Ikeda, I., Fujisawa, T., Takahashi, H., Yoneda, M., Hara, K., Abe, Y., Kirikoshi, H., Kubota, K., Saito, S., Ueno, N., Nakajima, A., Hamada, Y., Fukutomi, H., \& Satsuta, H. (2006). Blastocystis hominis infection in patient with regular dialysis. Journal of Gastroenterology, 41(6), 605-606. http://dx.doi.org/10.1007/s00535-006-1817-y. PMid:16868812.

Hirata, T., Nakamura, H., Kinjo, N., Hokama, A., Kinjo, F., Yamane, N., \& Fujita, J. (2007). Prevalence of Blastocystis hominis and Strongyloides stercoralis infection in Okinawa, Japan. Parasitology Research, 101(6), 1717-1719. http://dx.doi.org/10.1007/s00436007-0712-7. PMid:17717704.

Ishaku, A. A., Asheofo, D., Habibu, T., Sunday, T. M., Amuta, E. A., \& Azua, A. T. (2013). Prevalence of intestinal parasitic infections among food vendors in Lafia Metropolis of Nasarawa State, Nigeria. Scholarly Journals of Biotechnology, 2(2), 21-25.

Ismail, Y. (2016). Prevalence of parasitic contamination in salad vegetables collected from supermarkets and street vendors in Amman and Baqa'a - Jordan. Polish Journal of Microbiology, 65(2), 201-207. http://dx.doi.org/10.5604/17331331.1204480. PMid:30015444.

Leelayoova, S., Rangsin, R., Taamasri, P., Naaglor, T., Thathaisong, U., \& Mungthin, M. (2004). Evidence of waterborne transmission of Blastocystis hominis. The American Journal of Tropical Medicine and Hygiene, 70(6), 658-662. http://dx.doi.org/10.4269/ajtmh.2004.70.658. PMid:15211009.

Leelayoova, S., Sirpattanapipong, S., Thathaisong, U., Naaglor, T., Taamasri, P., Piyaraj, P., \& Mungthin, M. (2008). Drinking water: a possible source of blastocystis spp. subtype 1 infection in schoolchildren of a rural community in central Thailand. The American Journal of Tropical Medicine and Hygiene, 79(3), 401-406. http://dx.doi.org/10.4269/ajtmh.2008.79.401. PMid:18784233.

Luz, J. G. G., Barbosa, M. V., Carvalho, A. G., Resende, S. D., Dias, J. V. L., \& Martins, H. R. (2017). Contamination by intestinal parasites in vegetables marketed in an area of Jequitinhonha Valley, Minas Gerais, Brazil. Revista de Nutrição, 30(1), 127-136. http://dx.doi.org/10.1590/1678-98652017000100012

Macena, T. N. S., Ferreira, M. H. G., Santos, G. M. T., \& Souza, L. C. (2018). Análise parasitológica de alfaces servidas em restaurantes self-service do município de Teixeira de Freitas, BA. Revista Mosaicum, 27(27), 115-130. http://dx.doi.org/10.26893/rm.v15i27.55.

Machado, E. R., Maldonade, I. R., Riquette, R. F. R., Mendes, V. S., Gurgel-Gonçalves, R., \& Ginani, V. C. (2018). Frequency of enteroparasites and bacteria in the leafy vegetables sold in brazilian public wholesale markets. Journal of Food Protection, 81(4), 542-548. http://dx.doi.org/10.4315/0362-028X.JFP-17-358. PMid:29513106.

Medeiros, F. A., Oliveira, T. R., \& Málaga, S. M. R. (2019). Segurança dos alimentos: influência sazonal na contaminação parasitária em alface (Lactuca sativa L.) comercializada em feiras livres de Belém, Pará. Brazilian Journal of Food Technology, 22, e2018205. http://dx.doi.org/10.1590/1981-6723.20518. 
Melo, A. C. F. L., Furtado, L. F. V., Ferro, T. C, Bezerra, K. C., Costa, D. C. A., Costa, L. A., \& Silva, L.R. (2011). Contaminação parasitária de alfaces e sua relação com enteroparasitoses em manipuladores de alimentos. Revista Trópica - Ciências Agrárias e Biológicas, 5(3), 47-52. http://dx.doi.org/10.0000/rtcab.v5i3.335.

Mesquita, D. R., Silva, J. P., Monte, N. D. P., Sousa, R. L. T., Silva, R. V. S., Oliveira, S. S., Leal, A. R. S., \& Freire, S. M. (2015). Ocorrência de parasitos em alface-crespa (Lactuca sativa L.) em hortas comunitárias de Teresina, Piauí, Brasil. Revista de Patologia Tropical, 44(1), 67-76. http://dx.doi.org/10.5216/rpt.v44i1.34802.

Montanher, C. C., Coradin, D. C., \& Fontoura-da-Silva, S. E. (2007). Avaliação parasitológica em alfaces (Lactuca sativa) comercializadas em restaurantes self-service por quilo, da cidade de Curitiba, Paraná, Brasil. Estudos de Biologia, 29(66), 63-71. http://dx.doi.org/10.7213/reb.v29i66.22749.

Nogueira, V. D. F., Caseiro, M. M., \& Gagliani, L. H. (2016). Detecção de estruturas parasitárias em hortaliças comercializadas nos municípios de Santos e São Vicente - SP - Brasil. Revista UNILUS Ensino e Pesquisa, 13(33), 79-95. Retrieved in 2021, January 02, from http://revista.lusiada.br/index.php/ruep/article/view/775

Nomura, P. R., Ferreira, A. R. M., Rafaelli, R. A., Augusto, J. G., Tatakihara, V. L. H., Custódio, L. A., \& Murad, V. A. (2015). Estudo da incidência de parasitas intestinais em verduras comercializadas em feira livre e supermercado de Londrina. Semina. Ciências Biológicas e da Saúde, 36(1), 209-214. http://dx.doi.org/10.5433/1679-0367.2015v36n1Suplp209.

Oliveira, D. M., Novaes, B. C. B., Lucena, V. B., Souza, T. S., Barros, N. C. L., Dias, S. S., Silva, D. L., \& Correa, R. S. (2016). Perfil parasitológico do cheiro verde comercializado em feiras livres de Imperatriz - MA. Biota Amazônia, 6(2), 123-126. http://dx.doi.org/10.18561/2179-5746/biotaamazonia.v6n2p123-126.

Orlandi, P. A., Chu, D. M. T., Bier, J. W., \& Jackson, G. J. (2002). Parasites and the food supply. Food Technology, 56(4), $72-81$.

Oyeyemi, O. T., Agbaje, M. O., \& Okelue, U. B. (2016). Food-borne human parasitic pathogens associated with household cockroaches and houseflies in Nigeria. Parasite Epidemiology and Control, 1(1), 10-13. http://dx.doi.org/10.1016/j.parepi.2015.10.001.

Pan American Health Organization - PAHO. World Health Organization - WHO. (2003). Zoonoses and Communicable Diseases Common to Man and Animals. Parasitoses. Scientific and Technical Publication No. 580 (404p.). Geneva: WHO.

PAST. (2018). PAST v. 3.00. Retrieved in 2021, January 02, from https://www.softpedia.com/get/Science-CAD/PAST.shtml.

Paula, P., Rodrigues, P. S. S., Tórtora, J. C. O., Uchôa, C. M. A., \& Farage, S. (2003). Contaminação microbiológica e parasitológica em alfaces (Lactuca sativa) de restaurantes self-service, de Niterói, RJ. Revista da Sociedade Brasileira de Medicina Tropical, 36(4), 535-537. http://dx.doi.org/10.1590/S0037-86822003000400019. PMid:12937736.

Pedroso, R. C. C., Cunha, S. N., \& Cunha-Neto, A. (2020). Helmintos de importância para saúde pública em alfaces no Brasil: uma revisão sistemática. Brazilian Journal of health. RE:view, 3(6), 19200-19225. http://dx.doi.org/10.34119/bjhrv3n6-304.

Pinto, L. C., Gonçalves, M. N. L., Viana, M. W. C., Nascimento, M. P., Candido, A. S., \& Ferreira, R. J. (2018). Estruturas parasitárias em alface (Lactuca sativa L.), comercializadas na feira livre do município de Jardim, Ceará. Cadernos de Cultura e Ciências, 17(1), 1-14. Retrieved in 2021, January 02, from http://periodicos.urca.br/ojs/index.php/cadernos/article/view/1123

Quadros, R. M., Marques, S. M. T., Favaro, D. A., Pessoa, V. B., Arruda, A. A. R., \& Santini, J. (2008). Parasitos em alfaces (Lactuca sativa) de mercados e feiras livres de Lages - Santa Catarina. Revista Ciencias de la Salud, 1(2), 78-84. http://dx.doi.org/10.15448/1983-652X.2008.2.4368.

Queiroz, J. A. S., Torres, T. C., Reis, A. B., Lima, A. P., \& Alves, C. M. (2014). Avaliação parasitológica de alfaces (Lactuca sativa) comercializadas em restaurantes, supermercados, hortas e feira de Redenção, PA. Revista Brasileira de Análises Clínicas, 46(1-4), 83-86. Retrieved in 2021, January 02, from http://www.rbac.org.br/wp-content/uploads/2016/05/RBAC_Vol.46_ns1-4-Completa.pdf

Ramos, D. G. S., Scheremeta, R. G. A. C., Oliveira, A. C. S., Sinkoc, A. L., \& Pacheco, R. C. (2013). Survey of helminth parasites of cats from the metropolitan area of Cuiabá, Mato Grosso, Brazil. Revista Brasileira de Parasitologia Veterinária, 22(2), 201-206. http://dx.doi.org/10.1590/S1984-29612013000200040. PMid:23856737.

Ramos, I. C. N., Ramos, R. A. N., Giannelli, A., Lima, V. F. S., Cringoli, G., Rinaldi, L., Carvalho, G. A., \& Alves, L. C. (2019). An additional asset for the FLOTAC technique: detection of gastrointestinal parasites in vegetables. Acta Parasitologica, 64(2), 423425. http://dx.doi.org/10.2478/s11686-019-00059-3. PMid:31069644.

Ribeiro, G. M. R., Silva, V. H. F., Freitas, L. L., Fazolo, K. P., \& Fernandes, F. M. (2015). Avaliação parasitológica de alface (Lactuca sativa) comercializadas em feiras livres e supermercados de Muriaé, MG. Revista Científica da Faminas, 11(2), $49-57$. Retrieved in 2021, January 02, from http://periodicos.faminas.edu.br/index.php/RCFaminas/article/viewFile/110/95.

Robertson, L. J., Sprong, H., Ortega, Y. R., van der Giessen, J. W. B., \& Fayer, R. (2014). Impacts of globalization on foodborne parasites. Trends in Parasitology, 30(1), 37-52. http://dx.doi.org/10.1016/j.pt.2013.09.005. PMid:24140284.

Rodrigues, A. C., Silva, M. D. C., Pereira, R. A. S., \& Pinto, L. C. (2020). Prevalence of contamination by intestinal parasites in vegetables (Lactuca sativa L. and Coriandrum sativum L.) sold in markets in Belém, northern Brazil. Journal of the Science of Food and Agriculture, 100(7), 2859-2865. http://dx.doi.org/10.1002/jsfa.10265. PMid:31953861.

Rostami, A., Ebrahimi, M., Mehravar, S., Omrani, V. F., Fallahi, S., \& Behniafar, H. (2016). Contamination of commonly consumed raw vegetables with soil transmitted helminth eggs in Mazandaran province, northern Iran. International Journal of Food Microbiology, 225, 54-58. http://dx.doi.org/10.1016/j.ijfoodmicro.2016.03.013. PMid:26999768.

Santos, G. L. D., \& Peixoto, M. S. R. M. (2007). Detecção de Estruturas de enteroparasitas em amostras de alfaces (Lactuva sativa) comercializadas em Campina Grande, PB. NewsLab, 8, 142-150.

Silva, A. S., Silva, I. M. M., Rebouças, L. T., Almeida, J. S., Rocha, E. V. S., \& Amor, A. L. M. (2016). Análise parasitológica e microbiológica de hortaliças comercializadas no município de Santo Antônio de Jesus, Bahia (Brasil). Revista Visa em debate Sociedade. Ciência \& Tecnologia, 4(3), 77-85. http://dx.doi.org/10.22239/2317-269X.00655. 
Silva, C. G. M., Andrade, S. A. C., Stamford, T. L. M. (2005). Ocorrência de Cryptosporidium spp e outros parasitas em hortaliças consumida in natura, no Recife. Ciências e Saúde Coletiva, 10(suppl.), 63-69. https://doi.org/10.1590/S1413-81232005000500009.

Silva, E. P., Costa, R. A. M., Soares, M. A., Paulino, É. J., Murta, N. M. G., Morais, H. A., Dias, J. V. L., \& Pires, H. H. R. (2015). Aspectos higiênico-sanitários de feirantes e análise parasitológica de hortifrútis comercializados em feiras livres de municípios do estado de Minas Gerais, Brasil. Revista da Universidade Vale do Rio Verde, 13(2), 591-602. http://dx.doi.org/10.5892/ruvrd.v13i1.2447.

Silva, M. V., Pinto, L. C., Arrais, F. M. A., Costa, A. S., Silva, M. J. R., \& Ferreira, R. J. (2017). Estudo parasitológico de alface (Lactuca sativa L.) em alimentos fast food comercializados em festas populares do Cariri. Biota Amazônia, 7(3), 28-32. http://dx.doi.org/10.18561/2179-5746/biotaamazonia.v7n3p28-32.

Silva, T. A., Ávila, A. L. A., Antonelli, G., Silveira, M. B., Moreira, D. S. M., Lima, J. A. S., Castro, A. M., \& Rezende, H. H. A. (2019). Ocorrência de parasitos em frutas comercializadas nas ruas da cidade de Aparecida De Goiânia, Goiás, Brasil. Multi-Science Journal, 2(2), 68-71. http://dx.doi.org/10.33837/msj.v2i2.1054.

Soares, B., \& Cantos, G. A. (2005). Qualidade parasitológica e condições higiênico-sanitárias de hortaliças comercializadas na cidade de Florianópolis, Santa Catarina, Brasil. Revista Brasileira de Epidemiologia, 8(4), 377-384. http://dx.doi.org/10.1590/S1415$790 \times 2005000400006$.

Stensvold, C. R., Lebbad, M., \& Clark, C. G. (2012). Last of the human protists: the phylogeny and genetic diversity of lodamoeba. Molecular Biology and Evolution, 29(1), 39-42. http://dx.doi.org/10.1093/molbev/msr238. PMid:21940643.

Táparo, C. V., Perri, S. H. V., Serrano, A. C. M., Ishizaki, M. N., Costa, T. P., Amarante, A. F. T., \& Bresciani, K. D. S. (2006).

Comparação entre técnicas coproparasitológicas no diagnóstico de ovos de helmintos e oocistos de protozoários em cães. Revista Brasileira de Parasitologia Veterinária, 15(1), 1-5. PMid:16646994.

Terto, W. D. S., Oliveira, R. G., \& Lima, M. M. (2014). Avaliação parasitológica em alfaces (Lactuca sativa L.) comercializadas em Serra Talhada, Pernambuco, Brasil. Revista Visa em debate Sociedade. Ciência \& Tecnologia, 2(3), 51-57. http://dx.doi.org/10.3395/vd.v2i3.220.

Tiyo, R., Souza, C. Z., Piovesani, A. F., Tiyo, B. T., Colli, C. M., Marchioro, A. A., Gomes, M. L., \& Falavigna-Guilherme, A. L. (2016). Predominance of Giardia duodenalis Assemblage All in Fresh Leafy Vegetables from a Market in Southern Brazil. Journal of Food Protection, 79(6), 1036-1039. http://dx.doi.org/10.4315/0362-028X.JFP-15-306. PMid:27296610.

Trevisan, L., Pritsch, I. C., \& Molento, M. B. (2017). Análise parasitológica de amostras de agrião (Nasturtium officinale, Barbarea verna e Lepidium sativum) comercializadas em Curitiba e região metropolitana, Paraná, Brasil. Archives of Veterinary Science, 22(3), 50-56. http://dx.doi.org/10.5380/avs.v22i3.50962.

Utaaker, K. S., \& Robertson, L. J. (2015). Climate change and foodborne transmission of parasites: a consideration of possible interactions and impacts for selected parasites. Food Research International, 68, 16-23. http://dx.doi.org/10.1016/j.foodres.2014.06.051.

Vollkopf, P. C. P., Lopes, F. M. R., \& Navarro, I. T. (2006). Ocorrência de enteroparasitos em amostras de alface (Lactuca sativa) comercializadas em Porto Murtinho - MS. Arquivos de Ciências Veterinárias e Zoologia da UNIPAR, 9(1), 37-40. http://dx.doi.org/10.25110/arqvet.v9i1.2006.37.

World Health Organization - WHO. (2015). WHO estimates of the global burden of foodborne diseases: foodborne disease burden epidemiology reference group 2007-2015. Geneva: WHO.

Yusof, A. M., Mohammad, M., Abdullahi, M. A., Mohamed, Z., Zakaria, R., \& Wahab, R. A. (2017). Occurrence of intestinal parasitic contamination in select consumed local raw vegetables and fruits in Kuantan, Pahang. Tropical Life Sciences Research, 28(1), 2332. http://dx.doi.org/10.21315/tlsr2017.28.1.2. PMid:28228914.

Funding: Ministério da Ciência, Tecnologia e Inovação / Conselho Nacional de Desenvolvimento Científico e Tecnológico (Proj. No.151336/2020-2)

Received: Jan. 02, 2021; Accepted Sept 13, 2021

Associate Editor: Natan de Jesus Pimentel Filho 